\title{
Implementation of Ministrial Regulation of Education and Cultural, Number 28 of 2016 concerning Quality Assurance of Primary and Secondary Education in Medan City
}

\author{
Bahgie Mahtonami ${ }^{1}$, Darwin ${ }^{2}$, Arif Rahman ${ }^{3}$ \\ \{bahgiegie@gmail.com\} \\ Post Graduate of Educational Administration Study Program, Medan State University, Medan, \\ Indonesia
}

\begin{abstract}
This study aims to determine the implementation of Ministrial Regulation of Education and Cultural number 28 of 2016 concerning quality assurance of primary and secondary education in the city of Medan (case study at the North Sumatra Provincial Education Office). Data collection methods by observation and interview with the head of service. Checking the validity of the data was done by interviewing several heads of private vocational schools. The results of the study showed that the communication process was not carried out even by unscheduled socialization in the official work program. The consistency of staff communicating permendikbud to principals has not been implemented and scheduled regularly. The disposition that has been carried out is still in the form of information submitted from the Head of Service to official employees. but the information provided is not fully controlled by the staff, and related to internal coordination in the implementation of the policy has not run well and the external coordination between the Education Office and the headmaster is still not effective. The level of consistency in policy implementation has not been good, as seen from the absence of a specific schedule for training principals and to implement the policy.
\end{abstract}

Keywords: Policy implementation, education, quality assurance.

\section{Introduction}

Ministry of Education and Culture in 2016 in the draft Regulation of Minister of Education and Culture concerning quality assurance of primary and secondary education, Other facts that occur in the field related to quality assurance In the context of quality and quality assurance, the problems still faced are: Problems related to the meaning of quality assurance, Related issues with regulation, Problems related to determining and implementing quality assurance policies, Problems related to the essence of data, Problems related to honesty/ objectivity, Problems related to institutions. In connection with the foregoing, it is necessary to have a clear model or system description of the organizational form and implementation of the quality assurance system carried out by the North Sumatra provincial education office at the level of basic and middle education units in the city of Medan as a form of integrated efforts to improve the quality of education. 
H. Tachjan (2006) defines the implementation of policy as public policy is the process of administrative activities carried out after the policy is established [1]. This activity lies between the formulation of policies and the implementation of policy evaluation policies containinglogic top-down, which means lower / alternative interpreting. Nawawi suggests that policy implementation is the implementation of basic policy decisions, usually in the form of legislation, but can also in the form of important orders or executive decisions or decisions of the judiciary [2]. State that the success of the implementation of policies or programs can be addressed from three factors: (1) Perspective of compliance that measures the implementation of policies from compliance strains of the sea to their superiors; (2) The success of policy implementation is measured by the smooth routine and lack of problems; (3) Implementation of successful policies leads to performance that satisfies all parties, especially the expected beneficiary groups [3]. Solichin (1997) suggests that there are three factors that can lead to failure of policy implementation, namely: (1) policy issues. Policy implementation can fail because there are still uncertainties or internal or external insecurity or the policy itself, indicating a lack of resources related to help; (2) Information. Information shortages easily lead to an inaccurate picture of both the policy object and the implementers of the contents of the policy that will be implemented and the results of the policy; (3) Support. Implementation of public policy will be very difficult if the implementation is not enough support for the policy [3].

In general, the stages in policy making are described as a cycle that contains a formulation of the existing awareness: (1) Problems that require policy interference; (2) Defining the real problem, namely looking for causes or root causes, not the consequences arising from the problem; then (3) Identifying solutions to overcome these problems. Of the various solutions that exist then (4) Evaluated the most feasible options to do with considering the impact. Grindle says that in implementing a policy depends on the content (content) and context, and the success rate depends on the condition of the 3 variable components implementation resources needed [4]. These three components cause national programs to produce different variations of outputs and outcomes in the region. The three components are: Contents of policy messages,of policy messages, Credibility Policy form of. Modelperspective policy implementation Top-downdeveloped by George C. Edward III. Edward III named the model of Public policy Implementation with Direct and Indirect Impact on Implementation [5]. In the theoretical approach of George C. Edward III there are four variables that influence the successful implementation of a policy, namely: Communica-tion, Resources, Disposition, Bureaucratic Structure.

Policy implementation consists of a series of processes starting from: (1) data collection, (2) data analysis, (3) reporting / mapping, (4) preparation of recommendations, and (5) efforts to implement recommendations in the form of education quality improvement programs. Short (2009) suggests that the stages of the SPMP process are a cycle that is interrelated and takes place in a sustainable manner. The implementation of the above stages needs to be carried out collaboratively by various stakeholders in schoolaccordance with the mandate of the SBM [6]. Educational quality assurance is carried out on the basis of the principles of: Sustainability, Planned and Systematic „, Respecting the autonomy of formal and non-formal education units, Facilitating informal learning of sustainable communities with minimal state regulation, the SPMP is an open system that continues to be continuously improved. 


\section{Methodology}

This research is a policy research (policy research) that focuses on policy implementation research. S. Danim said, that policy research is one of the types of descriptive research with the aim of making recommendations needed by policy makers [7]. Research was carried out in the education office of the province of North Sumatra, with the consideration that the education office of the North Sumatra province was an institution/agency implementing education quality assurance policies in the city of Medan, especially the level of high school and vocational high schools both private and private, to obtain stronger information then some private Vocational Schools in Medan were chosen. The time of this research will be conducted from June 2018 until the saturated data has been obtained.

According to Moleong (2014), Data collection techniques that are generally carried out in qualitative research are observation, in-depth interviews, documentation studies [8]. Techniques analysis used in the analysis of this research are qualitative analysis, meaning that after the data is collected classified and then the data is processed and managed by the data using more sentence expressions as interpretations of the processed data.

\section{Result and Discussion}

In terms of delivering the message of the Education Office, North Sumatra province cannot be said to be good. because the message delivered by the Education office to the principal has not resulted in the implementation of a good policy. In addition, due to the absence of a specific schedule that was made to conduct training for principals in terms of implementation of quality assurance of education and seemed to consider it unimportant, the Ministry of Education and Culture had already been issued in 2016 but until 2018 it was still not well implemented. for school principals, the delivery of messages was only done briefly on the sidelines of training events that discussed other matters.

Information obtained by the ministry from the Ministry of Education and Culture is clear, but what is conveyed to the school principal by the Education office is still unclear, because the submission is less serious and well planned, this is evident by the delivery of the school principals training. which discusses other things. Thus the conclusion, in terms of clarity in the implementation of this policy, cannot be said to be good.

Information submitted by the Education Office to the principal regarding quality assurance can be said to be consistent and unchanging, this is also because the Permendikbud is still relatively new and no revisions have been made so that nothing has changed from the policy, but in carrying out the policy is still far from good. Quality assurance in the Education Office is good enough even though there is no structure, especially for the quality assurance team, because they are also placed in a position in accordance with their abilities and competencies, only upgrading or special training is needed to handle quality assurance to further hone the skills of the staff in quality assurance.

Information obtained by the Education office is quite clear, because indeed the contents of Ministrial Regulation of Education and Culture (so-called: Permendikbud) No. 28 of 2016 are clear about things that must be done and there are also guidelines for the implementation of education quality assurance, but the delivery procedures are not good and impressed. evenly received by all head of vocational schools, especially private vocational level. 
In relation to authority, the education office has authorized quality assurance staff and quality assurance staff to convey the authority to principals to assume responsibility for quality assurance in the schools they lead to improve the quality of education in the schools they lead. Availability of facilities in facilitating the implementation of quality assurance can be said to be good, this is evidenced by the availability of applications that make it easier for school operators and principals to communicate and take care of all kinds of things related to the quality assurance of Education in the way they lead.

Socialization regarding the implementation of Ministrial Regulation of Education and Culture, Number 28 of 2016 concerning quality assurance is far from good, this is evident from the lack of a specific schedule for conducting socialization activities to principals in North Sumatra, especially in Medan, so there is a need for improvement in this case. In terms of training the implementation of quality assurance Education for principals is still far from good and seems less serious, this is evident from the lack of training schedules for the implementation of education quality assurance for principals in the Education official work program and the Education quality assurance department in the city Medan at the SMK level.

Evaluation and monitoring activities can be said to be good, but the arrival schedule of supervisors is not evenly distributed and seems not the same, some come once a month, some come every two months. So the schedule for the visit of the supervisor to school must be improved and must be supervised so that the supervisor's visit to school is more routine and scheduled each month. Primarily the consistency of the implementation of Ministrial Regulation of Education and Culture No. 28 of 2016 cannot be said to be consistent, because the implementation has not been specifically scheduled and carried out only when there are other activities and inserted the implementation of the Ministrial Regulation of Education and Culture.

Looking at the flow of communication in this study, the Education Office and the heads of Private Vocational Schools have less intense relations and communication related to the implementation of this education quality assurance policy. The principal is very dependent on information from the education office as the main initial implementer, while the agency must also strive to socialize this policy to the principal for the sake of the implementation of the policy. In fact, in the field, the principal only carries out quality assurance according to the Foundation's instructions, without referring to Ministrial Regulation of Education and Culture, number 28 of 2016 and without referring to directives that should be submitted by the Education office. This led to a reason from the principal that they did not know who to ask, so they extracted information from the internet and other online media.

Sunber Primal has a good power, this is proven by the complete equipment that can be used to implement the quality assurance of Education, to the availability of online applications for quality assurance. However, the findings in the field have not been done at all in accordance with the policies written in the Ministry of Education and Culture. Even from three schools conducted observations and interviews. None of the schools have education quality assurance staff. And the problems found are in the case of financial facilities not yet budgeted through the APBD.

Looking at the implementation of Ministrial Regulation of Education and Culture conducted by the education office for private vocational schools, it has not had a positive impact, and even it seems that there has been no impact at all, private Vocational Schools conduct their own quality assurance without any meaningful interference from the education office, they perform quality assurance at their schools by looking at what is needed by the school and its students, and based on the rules issued by the Foundation or the school leadership. Other evidence, it appears from schools that have not formed a special team to 
conduct and administer education quality assurance at the school. So what can be drawn from the overall data above is that, starting from the issuance of Ministrial Regulation of Education and Culture number 28 of 2016 up to now and the implementation carried out by the education office, it has not had good consistency and has not given meaningful impact to private vocational schools in the city of Medan.

\section{Conclusion}

The process of communication, lack of socialization process. Based on observations and interviews conducted in three schools, socialization has not been carried out by the North Sumatra Provincial Education Office on a scheduled basis.

Resources, the availability of information is still very minimal when compared to the availability of other educational information such as teacher certification. the authority of the Education Office should be the mediator of the implementation of the quality assurance of Education, but the authority is still far from good. the facilities, both in the form of facilities and infrastructure and financial facilities in their implementation, are already good problems, this is evidenced by the complete equipment that can be used to implement implementation, to the availability of online applications for quality assurance. But the absence is carried out in accordance with the policy written in the Ministry of Education and Culture. And another problem is in the case of financial facilities not yet budgeted through the APBD.

Consistency in implementation, there has never been any socialization in the form of training, training, or workshops by the Education Office. the implementation has not been said to have good consistency and has not been too positive, and even impressed that there has been no impact.

\section{References}

[1] Tachjan, Public Policy Implementation. Bandung: AIPI, 2006.

[2] I. Nawawi, Public Policy (Analysis, Theory and Practice Advocacy Strategy). Surabaya: PMN, 2009.

[3] A. Solichin, Introduction to Public Policy Analysis. Malang: University of Muhammadiyah Malang Press, 2008.

[4] M. Grindle, "Politics and Policy Implementation in The Third World," Princnton Unifrsity Press, 1980.

[5] L. E. O. Agustino and M. A. Yusoff, "Proliferasi dan Etno-Nasionalisme daripada Pemberdayaan dalam Pemekaran Daerah di Indonesia," vol. 15, pp. 196-201, 2008.

[6] “Government Regulation No. 19 of 2005," 2005.

[7] S. Danim, Pengantar Studi Penelitian Kebijakan. Jakarta: Bumi Aksara, 2010.

[8] L. Moleong, Metodologi Penelitian Kualitatif. Bandung: Remaja Rosdakarya, 2014. 